\title{
STRUKTUR KOMUNITAS IKAN FAMILY CHAETODONTIDAE SEBAGAI INDIKATOR KONDISI KESEHATAN LINGKUNGAN EKOSISTEM TERUMBU KARANG DI ZONA TRADISIONAL PULAU BUNAKEN TAMAN NASIONAL BUNAKEN
}

\author{
(Community Structure of Family Chaetodontidae as Environment Healthy Condition
} Indicator of Coral Reef Ecosystem at Traditional Zone in Bunaken National Park )

\section{Frengki Palendeng ${ }^{1 *}$, Janny D. Kusen ${ }^{2}$, Indri S. Manembu ${ }^{2}$, Farnis B. Boneka ${ }^{2}$, Calvyn F. A. Sondakh², Billy Wagey ${ }^{2}$, Adnan S. Wantasen ${ }^{3}$}

1. Mahasiswa Program Studi IImu Kelautan, FPIK, UNSRAT Manado

2. Staf Pengajar Program Studi IImu Kelautan, FPIK, UNSRAT Manado

3. Staf Pengajar Program Studi Manajemen Sumberdaya Perairan, FPIK UNSRAT Manado

Penulis korespondensi: Frengki Palendeng; frengkipalendeng@gmail.com

\begin{abstract}
The presence of coral reef fishes, especially family Chaetodontidae is one of bioindicators to environment health condition of coral reef. Fish indicator research in Bunaken Island waters aims to find out the community structure, such as the composition, abundance, density, equality, diversity and dominance. Data collection was conducted at 5 (five) locations in the Bunaken Island Traditional Zone where there are 5 (five) observation points respectively, namely TP-1 Mandolin, TP-2 Alung Banua, TP3 Sachiko, TP-4 Muka Kampung, and TP-5 Bunaken Timur. Data collection by underwater visual census (UVC) techniques using SCUBA. The results showed there were 23 species of indicator fish from family Chaetodontidae, total individuals number of each species in 5 research sites as many as 97 individuals. The highest fish density is 0.06 at TP- 5 while the lowest value in TP- 2 with density value 0.02 . Through indicator fish community structure indicates that the coral reef quality conditions is stable indicated by diversity values $\left(\mathrm{H}^{\prime}\right)$ in all locations were moderate category and inversely proportional by low dominance values, high leveling values $(E)$. The similarity rate (IS) of indicator fish species in all locations differs from each other indicating the condition of coral reefs in each location grows independently without being influenced by other locations.
\end{abstract}

Keywords: Reef Fish, Coral Reef, Indicator Fish.

\section{ABSTRAK}

Keberadaan ikan karang, khususnya ikan-ikan family Chaetodontidae merupakan salah satu bioindikator terhadap kondisi kesehatan lingkungan terumbu karang yang baik. Penelitian ikan indikator di perairan Pulau Bunaken bertujuan untuk mengetahui struktur komunitas yaitu komposisi jenis, kelimpahan, kepadatan, kemerataan, kesamaan, keanekaragaman dan dominansi. Pengumpulan data dilakukan pada 5 (lima) lokasi di Zona Tradisional Pulau Bunaken dimana pada tiap lokasi ada 5 (lima) titik pengamatan yaitu TP-1 Mandolin, TP-2 Alung Banua, TP-3 Sachiko, TP-4 Muka Kampung, dan TP-5 Bunaken Timur. Pengambilan data menggunakan teknik Underwater Visual Census (UVC) dengan peralatan SCUBA. Hasil penelitian menunjukan terdapat 23 spesies ikan indikator dari famili Chaetodontidae dengan total jumlah individu dari tiap spesies di 5 lokasi penelitian sebanyak 97 individu. Kepadatan ikan tertinggi yaitu 0.06 berada pada TP-5 sedangkan nilai kepadatan terendah di TP-2 dengan nilai kepadatan 0.02 . Struktur komunitas ikan indikator menunjukkan kondisi kualitas terumbu karang stabil yang diindikasikan dengan nilai keanekaragaman $\left(\mathrm{H}^{\prime}\right)$ di semua lokasi dalam kategori sedang yang berbanding terbalik dengan nilai dominansi yang rendah, nilai kemerataan (E) tinggi. Tingkat kesamaan (IS) spesies ikan indikator pada kelima lokasi berbeda satu dengan yang lainnya menunjukkan kondisi terumbu karang di tiap-tiap lokasi bertumbuh secara independen tanpa saling dipengaruhi oleh lokasi lain.

Kata Kunci: Ikan karang, Terumbu karang, Ikan Indikator. 


\section{PENDAHULUAN}

Taman Nasional Bunaken (TNB) merupakan kawasan pelestarian alam berbasis pulau dan laut yang dikelola oleh pemerintah dan ditetapkan berdasarkan SK. Menteri Kehutanan No 730/KPTSII/1991 dengan luas 89.065 Ha. Dalam optimalisasi fungsi dan peran Taman Nasional maka dikelola dengan sistim zonasi, salah satunya yaitu Zona Tradisional sebagai bagian dari Taman Nasional yang ditetapkan untuk kepentingan pemanfaatan secara tradisional oleh masyarakat yang karena kesejarahannya tergantung dengan sumber daya alam yang ada disitu.

Ekosistem terumbu karang di Taman Nasiona Bunaken khususnya di Zona Tradisional saat ini telah mengalami degradasi. Beban limbah dan sampah yang dibuang di Teluk Manado secara terus menerus, penambahan penduduk di dalam kawasan serta aktivitas penangkapan ikan dan pariwisata yang tidak ramah lingkungan memberikan andil bagi degradasi ekosistem terumbu karang di dalam kawasan Taman Nasional Bunaken.

Sangat kompleksnya dinamika berbagai faktor penyebab degradasi yang terjadi di kawasan terumbu karang menjadi permasalahan yang serius dalam keberlanjutan ekosistem. Untuk mengetahui kondisi terumbu karang dibutuhkan pemantauan (monitoring); salah satunya yaitu melalui pengamatan jenis ikan tertentu yang hidup pada ekosistem ini.

Ikan dari kelompok Chaetodon merupakan indikator ekologi bagi terumbu karang Kusen, dkk. (2016). Beberapa alasan pemilihan ikan family
Chaetodontidae sebagai indikator karena tergolong kelompok family penting dan banyak dipelajari tentang kehidupannya di karang (Williams dan Hatcher, 1983). Reese (1981) dan Hourigan, dkk. (1988) mengemukakan bahwa ikan-ikan kelompok famili Chaetodontidae memiliki asosiasi yang kuat dengan karang dan dapat digunakan sebagai indikator kesehatan ekosistim terumbu karang.

Salah satu wilayah yang menjadi tempat pemanfaatan ikan karang oleh masyarakat nelayan Pulau Bunaken adalah zona tradisional yang termasuk dalam wilayah Taman Nasional Bunaken. Dengan tingkat aktivitas perikanan terumbu yang sudah berlangsung cukup lama di lokasi tersebut, maka sangat diperlukan data struktur komunitas ikan karang khususnya ikan indikator guna kepentingan usaha pengelolaan terumbu karang di wilayah tersebut.

\section{METODE PENELITIAN}

Lokasi penelitian yaitu di rataan terumbu (reef flat) yang dikenal sebagai Zona Tradisional Pulau Bunaken Taman Nasional Bunaken pada posisi geografis Madolin pada titik koordinat N 1036'49.58" E 124\%46'56.53", Alung Banua N 1037'47.00" E 124²6'18.08", Sachiko N 1036'47.16" E 124⒋'1.90", Muka

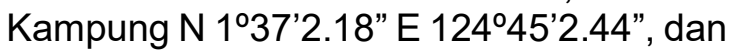
Bunaken Timur N 1035'50.48” E 12446'11.26" (Gambar 1). Data ikan karang yang dikoleks di Zona Tradisional pada 5 (lima) Titik Pengamatan (TP) yaitu TP-1 Mandolin, TP-2 Alung Banua, TP-3 Sachiko, TP-4 Muka Kampung, dan TP-5 Bunaken Timur. 




Gambar 1. Peta lokasi penelitian

Pengambilan data ikan karang menggunakan metode sensus visual bawah air (Underwater Visual Census, UVC) mengikuti English, et al. (1994) yang terdiri dari dua tahap yaitu tahap persiapan dan pengamatan. Selanjutnya dilakukan peletakan transek sepanjang $100 \mathrm{~m}$ pada kedalama 5-6 meter. Pengambilan data di setiap lokasi penelitian dilakukan dengan cara mencatat spesies dan jumlah ikan karang yang ditemukan di tiap stasiun dengan jarak pandang 2,5 meter ke kiri dan kanan dari garis transek.

\section{a. Analisa Data}

Analisis data sesuai parameter struktur komunitas yang diukur yakni : komposisi jenis, indeks kepadatan mutlak, keanekaragaman, dominasi, kemerataan dan kesamaan komunitas ikan indikator tiap stasiun penelitian (TP).

\section{Komposisi Jenis}

Komposisi jenis (KJ) adalah perbandingan antara jumlah individu masing-masing jenis dengan jumlah total jeis ikan yang di temukan. Komposisi jenis ikan karang dihitung menurut rumus (Setyobudiandi, dkk. 2009)

$$
\mathrm{KJ}=\frac{\mathrm{ni}}{\mathrm{N}} \times 100
$$

Keterangan :

$\mathrm{KJ}=$ komposisi jenis (\%)

$\mathrm{ni}=$ jumlah individu tiap spesies

$\mathrm{N}=$ jumlah individu seluruh spesies
2. Indeks Kepadatan Mutlak

Untuk menghitung kepadatan mutlak dilakukan dengan rumus oleh (Odum, 1971):

$$
K=\frac{n i}{L}
$$

Keterangan :

$$
\begin{aligned}
& \mathrm{K}=\text { Kepadatan } \\
& \mathrm{ni}=\text { jumlah total individu spesies- } \mathrm{i} \\
& \mathrm{L}=\text { luas total daerah yang } \\
& \text { disampel. }
\end{aligned}
$$

\section{Indeks Keanekaragaman}

Untuk menghitung indeks keanekaragaman ikan karang digunakan rumus indeks keanekaragaman yang dikemukakan oleh Shannon dan Wiener (Odum, 1971) yang dirumuskan sebagai berikut:

$$
H^{\prime}=-\sum n i / N X \operatorname{Ln} \mathrm{ni} / \mathrm{N}
$$

Keterangan:

$\mathrm{H}^{\prime}=$ Indeks Keanekaragaman

$\mathrm{ni}=$ Jumlah total individu per spesies

$\mathrm{N}=$ Jumlah total individu seluruh spesies

Dimana :

$\mathrm{H}^{\prime}<1.5$ menunjukkan keanekaragaman jenis tergolong rendah

$H^{\prime}=1.5-3.5$ menunjukkan keanekaragaman jenis tergolong sedang

$\mathrm{H}^{\prime}$ > 3.5 menunjukkan keanekaragaman jenis tinggi

\section{Indeks Dominasi}


Indeks Dominansi (D) digunakan untuk melihat kondisi apabila ada terjadinya dominasi suatu jenis tertentu di dalam komunitas ikan karang. Indeks yang digunakan dalam analisis ini yaitu Indeks Dominansi Simpson (Odum,1971) sebagai berikut:

$$
D=\sum_{i=1}^{n}\left(\frac{n i}{N}\right)^{2}
$$

Keterangan:

D : Indeks Dominansi

$\mathrm{Ni}$ : Perbandingan jumlah ikan karang spesies ikan karang ke-1 (ni)

$\mathrm{N}$ : Jumlah total individu

Kisaran nilai indeks dominansi tersebut yaitu:

$0,00<0,30$ : Dominansi rendah.

$0,30<0,60$ : Dominansi sedang.

$0,60<1,00$ : Dominansi tinggi.

\section{Indeks Kemerataan}

Menurut Odum (1971) untuk menghitung Indeks Kemerataan (E) dilakukan dengan rumus sebagai berikut:

$$
E=\frac{H \prime}{\ln (S)}
$$

Keterangan:

$\mathrm{e}=$ indeks kemerataan

$\mathrm{H}^{\prime}=$ Keanekaragaman

(S) = Jumlah spesies

Dimana:

$\mathrm{E}<0.3$ menunjukkan kemerataan jenis tergolong rendah

$\mathrm{E}=0.3$ - 0.6 menunjukkan kemerataan jenis tergolong sedang

$\mathrm{E}>0.6$ menunjukkan kemerataan jenis tergolong tinggi

\section{Indeks Kesamaan Komunitas}

Indeks ini dikemukakan oleh Kendeight (1974) suatu aturan acuan 50\%, yaitu dua komunitas dinyatakan sama jika memiliki nilai Indeks Kesamaan (IS) sama atau lebih besar dari 50\%. Untuk mengetahui kesamaan komunitas ikan berdampak terhadap kondisi terumbu karang sehingga berpengaruh terhadap populasi ikan karang.

$$
I S \frac{2 C}{A+B} X 100
$$

Keterangan :

IS = Indeks Kesamaan jenis

Sorensen (nilai anatar 0-1)

$\mathrm{C}=$ Jumlah jenis ikan yang sama di kedua area $A$ dan $B$

$A=$ Jumlah jenis ikan di Area $A$

$B=$ Jumlah jenis ikan di Area

\section{HASIL DAN PEMBAHASAN 1. Jenis Ikan Family Chaetodontidae}

Identifikasi jenis ikan mengunakan buku identifikasi menurut Allen (1997). Hasil identifikasi untuk jenis-jenis ikan indikator ditemukan 23 spesies dari family Chaetodontidae dengan total jumlah imdividu per spesies sebanyak 97 individu. Jenis yang ada di semua TP yaitu Hemitaurichthys polylepis. Sama dengan penelitian oleh Setiawan, dkk (2013) di perairan terumbu karang Taman Nasional Bunaken dari 30 spesies ikan indikator yang ditemukan jenis Hemistaurichthys polylepis ditemukan di semua stasiun penelitian.

\section{Komposisi Jenis}

Hasil komposisi jenis ikan indikator di semua Titik Pengamatan (TP) diperoleh 23 spesies dari famili Chaetodontidae dengan komposisi jenis yang tertinggi yaitu Chaetodon lunulatus 25\% TP-1, Chaetodon kleinii 30\% TP-2, Forcipiger longirostris 15,79\% TP-3, Chaetodon citrinellus 17,65\% TP-4, Hemitaurichthys polulepis $34,29 \%$ TP-5. Dari hasil komposisi jenis ikan indikator di kelima TP menunjukan bahwa Hemitaurichthys polulepis merupakan spesies dengan jumlah individu terbanyak yaitu 12 individu dan terdapat satu spesies yang berada dalam semua TP yaitu Chaetodon kleinni. Untuk komposisi tertinggi berada pada TP2 yaitu 30\% dan yang paling rendah berada pada TP-5 yaitu 2,86

\section{Indeks Kepadataan}

Dari hasil perhitungan indeks kepadatan mutlak atau kepadatan total dari 
semua TP terdapat satu TP dengan nilai kepadatan tertinggi yaitu 0.06 di TP-5 sedangkan pada TP-1, TP-3, TP-4 nilai kepadatan relatif sama yaitu 0.03 , sedangkan nilai kepadatan terendah berada pada TP-2 dengan nilai kepadatan 0.02 (Gambar 2). Rondonuwu, dkk. (2017) mengemukakan bahwa setiap spesies ikan karang akan memperlihatkan preferensi/kecocokan terhadap habitat tertentu. Artinya, habitat yang cocok akan menentukan kelimpahan ikan tersebut sehingga dapat disimpulkan bahwa kondisi terumbu karang pada TP-5 lebih menunjang kepadatan dibandingkan dengan TP yang lain karna nilai kepadatan pada TP-5 paling tinggi. Di sisi lain, lokasi TP-5 merupakan salah satu kawasan yang aktivitas antropogenik relatif rendah, kegiatan wisata bawah air juga tidak terlalu intensif karena arus yang cukup keras. Sedangkan untuk TP-1 merupakan salah satu kawasan yang aktivitas eksploitasi ikan-ikan karang di 'reef flat' (rataan terumbu) atau Zona Tradisional yang cukup intensif.

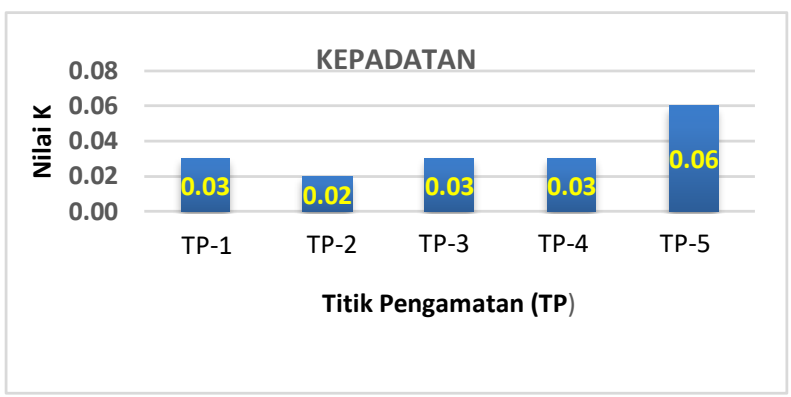

Gambar 2. Nilai Indeks Kepadatan Total

\section{Indeks keanekaragaman}

Indeks Keanekaragaman ( $\left.\mathrm{H}^{\prime}\right)$ dapat diartikan sebagai suatu penggambaran secara sistematik yang melukiskan struktur komunitas dan dapat memudahkan proses analisa informasi-informasi mengenai macam dan jumlah organisme (Insafitri, 2010). Dari analisis Indeks Keanekaragaman $\left(\mathrm{H}^{\prime}\right)$ yang didapatkan dari 5 Titik Pengamatan yaitu dengan rentang nilai $H^{\prime}$ antara 1.7 - 2.6 dengan nilai $\mathrm{H}^{\prime}$ tertinggi berada pada TP-3 dan nilai terendah berada pada TP-2 (Gambar 3). Berdasarkan hasil analisis parameter indeks keanekaragaman $\left(\mathrm{H}^{\prime}\right)$ dapat dinyatakan bahwa keanekaragaman jenis ikan karang di semua lokasi Titik Pengamatan di Zona Tradisinal Pulau Bunaken (Gambar 4) menunjukan keanekaragaman jenis kategori sedang, karena $H^{\prime}=1.5-3.5$ (Odum, 1971). Sesuai yang dikemukakan Odum (1971) bahwa keanekaragaman tergolong kategori sedang diduga karena ada perubahan dari kondisi stabil dan berubah oleh pengaruh lingkungan. Diketahui bahwa Zona Tradisional merupakan zona yang biasa dimanfaatkan oleh masyarakat baik penankapan ikan terbatas dan pariwista bawah air, sehinga banyak terjadi kegiatan anthropogenik yang diduga menyebabkan keanekaragaman dalam kategori sedang.

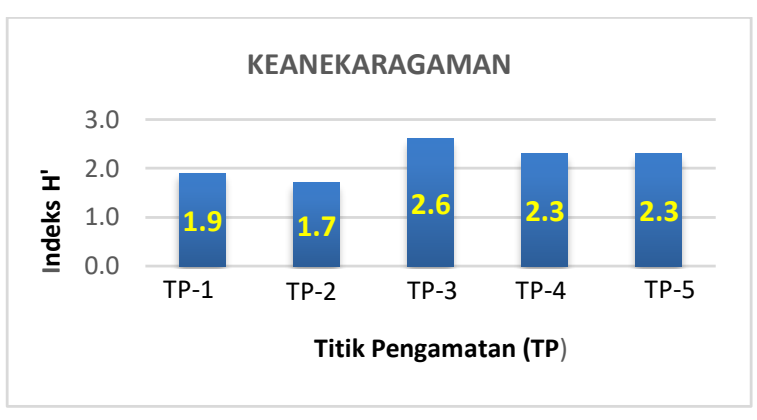

Gambar 3. Nilai Indeks Keanekaragaman

\section{Indeks Dominasi}

Dari hasil analisis Indeks Dominasi pada pengamatan di 5 Titik Pengamatan (TP), (Gambar 4) menunjukan nilai Indeks Dominasi (D) dalam rentang 0.08 - 0.20. Hasil analisis ini menunjukan bahwa nilai Dominasi (D) dari ke 5 Titik Pengamatan (TP) pengamatan tergolong dalam kategori rendah yaitu pada rentang $0.00-0.30$ (Odum, 1971): Namun pada TP-5 terdapat satu spesies yang banyak ditemukan yaitu jenis Hemitaurichthys polylepis dengan jumlah 12 individu. Rendahnya Indeks Dominansi berbanding terbalik dengan nilai keanearagaman $\left(H^{\prime}\right)$. menunjukkan tidak banyak spesies yang dominan dan variasi spesies ikan karang masih cukup beranekaragam. Sekalipun Indeks H' di lokasi penelitian dalam kategori sedang. Hubungan yang berbanding terbalik ini 
menunjukkan bahwa kondisi kesehatan lingkungan ekosistem terumbu karang yang stabil.

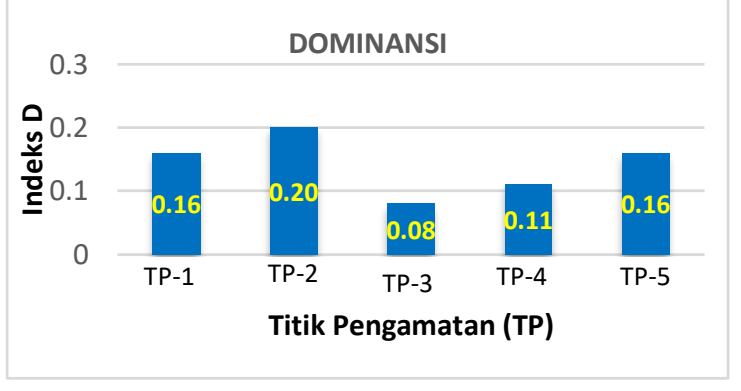

Gambar 4. Nilai Indeks Dominansi

\section{Indeks Kemerataan}

\section{Indeks Kemerataan}

menggambarkan jumlah individu antar spesies dalam suatu komunitas ikan yang merata. Semakin merata penyebaran individu antar spesies maka keseimbangan ekosistem akan semakin meningkat (Odum, 1993). Dari perhitungan analisis Indeks Kemerataan pada semua Titik Pengamatan menunjukan bahwa nilai Kemerataan (E) berkisar antara 0.9 - 1.0 (Gambar 5) dan nilai ini menunjukan kemerataan tergolong tinggi nilai Indeks Kemerataan $\mathrm{E}>0.6$ menunjukkan kemerataan jenis tergolong kategori tinggi. Ini juga dapat dilihat dari nilai dominasi yang tergolong rendah karena jika ada spesies yang mendominasi maka kemerataan akan menurun dan sebaliknya jika dominasi rendah maka kemerataan akan tinggi, atau hubungan berbanding terbalik antara kedua parameter. Tingginya Indeks Kemerataan (E) menunjukkan kondisi lingkungan terumbu karang dalam kategori baik, sehingga memberi peluang bagi hampir semua ikan-ikan yang berasosiasi dengan terumbu karang.

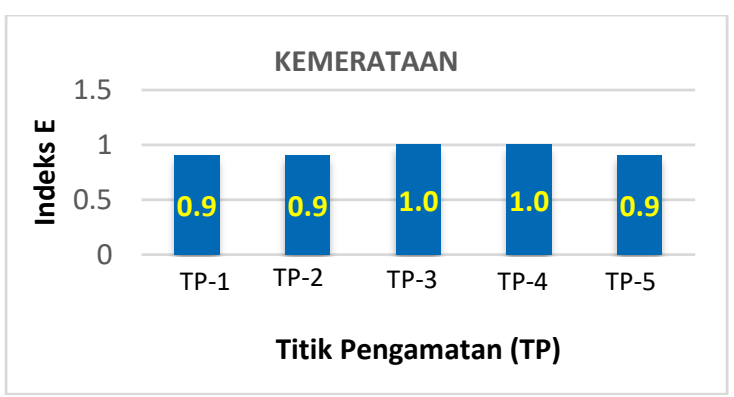

Gambar 5. Nilai Indeks Kemerataan

\section{Indeks Kesamaan Komunitas}

Hasil yang didapatkan menunjukan bahwa kesamaan pada kelima lokasi pengamatan dikatakan berbeda (Gambar 6), karena Kendeigh (1974) menyatakan suatu aturan $50 \%$, yaitu dua komunitas dinyatakan sama jika memiliki nilai kesamaan sama atau lebih besar dari 50\%. jadi pada kelima titik pengamatan memiliki perbedaan karna nilai yang didapatkan tidak melebihi 50\% .. Zona tradisional di Pulau Bunaken Taman Nasional Bunaken diketahui mrupakan kawasan yang cukup tinggi kegiatan antropogeniknya, selain cukup tinggi aktivitas wisata bawah air, juga sering terjadi kegiatan eksploitasi ikan karang oleh masyarakat.

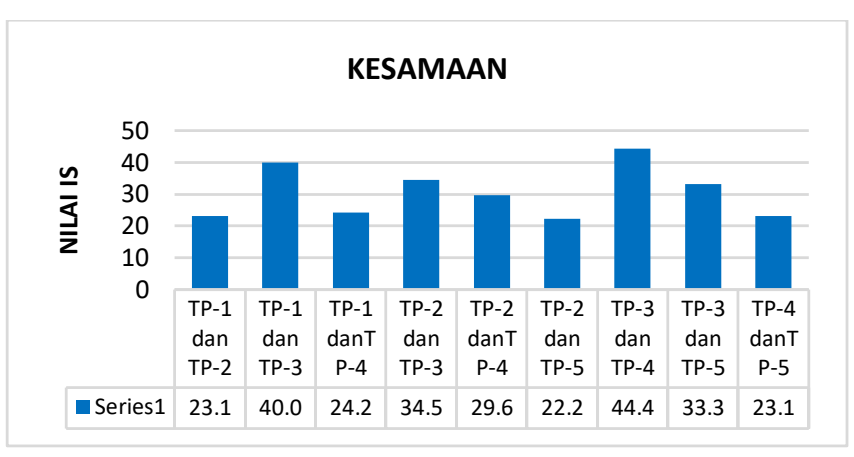

\section{Gambar 6. Nilai Indeks Kesamaan}

\section{KESIMPULAN}

Terdapat 23 spesies ikan indikator dari famili Chaetodontidae dengan total jumlah individu dari tiap spesies di 5 lokasi penelitian berjumlah 97 individu. Kepadatan ikan indikator tertinggi berada pada TP-5 (Bunaken Timur) di bandingkan dengan lokasi lainnya.

Struktur komunitas ikan indikator menunjukkan kondisi kualitas terumbu karang yang stabil, keanekaragaman $\left(\mathrm{H}^{\prime}\right)$ di semua lokasi penelitian kategori sedang, kemerataan $(E)$ yang tinggi berimbang dengan dominasi berkategori rendah. Tingkat kesamaan (IS) spesies ikan 
indikator pada kelima lokasi berbeda satu dengan yang lainnya menunjukkan kondisi terumbu karang di tiap-tiap lokasi bertumbuh secara independen tanpa saling dipengaruhi oleh lokasi lain. Hasil analisis mengindikasikan bahwa kondisi kesehatan lingkungan ekosistem terumbu karang Taman Nasional Bunaken dalam keadaan stabil.

\section{DAFTAR PUSTAKA}

Allen, G. R. 1997. A Field Guide for Anglers and Divers. Marine Fishes of Tropical Australia and South-East Asia. Western Australian museum, $292 \mathrm{pp}$.

English S, Wilkinson C, \& Baker V. 1994. Survey Manual for Tropical Marine Resources. Australian Institute of Marine Science. Townsville. Australia.

Insafitri. 2010. Keanekaragaman, Keseragaman dan Dominansi Bivalvia Di Area Buangan Lumpur Lapindo Muara Sungai Porong. Jurnal Kelautan, Volume 3, No.1, 54-59.

Kendeigh, S. C. 1974. Ecology with special reference to animals and man. Prentice-Hall New Jersey: 474 p.

Kusen, J. Lumingas, L. Rondo, M. 2016. Ekologi Laut Tropis. Penerbit Fakultas Perikanan dan IImu Kelautan Universitas Sam Ratulangi. Manado.

Odum, E.P. 1971. Fundamental Ecology, W.B Sauders, Co, London. 574 p.

Odum, E.P. 1993. Dasar-Dasar Ekologi. Penerjemahan: Samingan, $T$ dan B. Srigandono. Gajahmada University Press. Yogyakarta. 697 p.
Reese E. S. 1981. Predation on corals by fishes of the family Chaetodontidae: implications for conservation and management of coral reef ecosystems. Bull. Mar. Sci., 31: 594-604.

Rondonuwu, A.B., L.J. L. Lumingas, N.E. Bataragoa, 2017. Coral Fishes of Chaetodontidae in North Salawaty and South Batanta Districts, Raja Ampat Regency, West Papua Province. Jurnal IImiah Platax Vol. 5:(2), Januari 2017, ISSN: 23023589. Hal. 21-28.

Setiawan, F., Janny D.K., \& Georis J.F.K. 2013. Struktur Komunitas Ikan karang di perairan terumbu karang taman nasional bunaken, sulawesi utara. Jurnal Perikanan dan Kelautan tropis. 9(1):13-18

Setyobudiandi, I., Sulistino., F. Yulianda., C. Kusmara, C., S. Hariyadi., A. Damar., A. Sembiring dan Bahtiar. 2009. Sampling dan Analisis Data Perikanan dan Kelautan; Terapan Metode Pengambilan Contoh di Wilayah Pesisir dan Laut. Fakultas Perikanan dan Ilmu Kelautan. Insitut Pertanian Bogor. Bogor

Williams, D. McB., \& A.I. Hatcher. 1983. Structure of fish communities on outer slopes of inshore, mid-shelf and outer shelf reefs of the Great Barrier Reef. Mar. Ecol. Prog. Ser. 10: 239-250. 